\title{
Gender and the Politics of Knowledge
}

\author{
Mary Ann Dzuback
}

Contentious public debates about women's rational and moral capacity circulated during the European Enlightenment at the same time that science was emerging as a dominant mode of inquiry. As historian Karen Offen argues in European Feminisms, these debates preoccupied both men and women intellectuals of the middling and upper classes and represented a pivotal moment in the three-century campaign to rearticulate a politics of knowledge proclaiming women as deserving as men of formal schooling at all levels. Disputes about women's capabilities emerged in the context of efforts to redefine the rights and privileges of men, of male intellectuals to reassert male dominance over and control of females' access to intellectual participation as well as the craft guilds associated with women's work, and of men and women to consider the meaning and structure of social institutions and social systems. The German poet Philippine Engelhard captured women's frustrations with the limits imposed upon them in comparison to men in the context of the formation of the liberal state, the development of the middle class, and the growth of humanistic and scientific inquiry:

How oft with damnation

And tears of frustration

My gender I curse!

Its ban ever dooms

Us girls to our rooms;

How freely men move!

Even youngster and serf. ${ }^{1}$

Privileged women in the convents had had access to advanced formal learning from the sixth to the eleventh centuries. But during the period of

Mary Ann Dzuback is Associate Professor of Education and History in the Department of Education at Washington University. The author would like to thank the Spencer Foundation for supporting the research for the larger project on women academic social scientists and Washington University for the sabbatical to draft the chapter that is the basis of this address. She also thanks Peter Best and the editors of the History of Education Quarterly for their close reading and suggestions for improving this article. This article was presented as the presidential address to the History of Education Society's annual meeting, Pittsburgh, 31 October-03 November 2002.

${ }^{1}$ Karen Offen, European Feminisms, 1700-1950: A Political History (Stanford, CA: Stanford University Press, 2000), chapter 1; Engelhart quoted 41-42.

History of Education Quarterly Vol. $43 \quad$ No. 2 Summer 2003 
university formation, from the twelfth to the seventeenth centuries, women were excluded from such learning except in those convents that maintained possession of their wealth and libraries during the Reformation. A small number of intellectuals had argued for women's equality with men throughout the fifteenth and sixteenth centuries. As early as 1622, Marie Jars de Gournay claimed that women and men were essentially equal, that differences in ability were not innate, but cultural, because women did not have the same access to education and knowledge that men did. The development of Cartesian philosophy was an intellectual catapult, according to Londa Scheibinger. As early as 1673, for example, a French cleric, François Poullain de la Barre, asserted "the mind has no sex." Such a claim placed the discussion within the realm of philosophy and enabled others to draw on it in the eighteenth century. ${ }^{2}$

During the Enlightenment a number of factors and conditions converged, which made the debate increasingly public in fiction, poetry, plays, pamphlets, and other print media. Expanded literacy among men and women and an explosion of print culture increased women's ability to participate publicly, to criticize male dominance of intellectual life, and to articulate a feminist challenge to existing gender relations that placed women subordinate to men and denied them access to the same rights and privileges. One of the first among these privileges was education. An early advocate of women's advanced learning, Mary Astell, argued in 1694 that women could reason as well as men; she urged the establishment of a women's university and female scholarly communities. In the 1730s, European women had concrete proof that it was possible to succeed in such an environment when the University of Bologna awarded a doctorate in philosophy to Laura Bassi, who became a professor of physics there and annually presented papers on her research. Italian universities, by granting a small number of doctorates to women and employing women as lecturers in law, sciences, and mathematics (particularly at Bologna), were the exception to European higher education institutions. ${ }^{3}$

Throughout the eighteenth century the discussion of women's rights and women's education evinced a significant range of views. Some claimed, like Rousseau in Emile, that man was intellectually superior to woman and that woman's primary social contributions were her beauty and her ability to provide emotional support and care to men and children. Mary Wollstonecraft contended that "not only the virtue, but the knowledge of the two

${ }^{2}$ Londa Schiebinger, The Mind Has No Sex? Women in the Origins of Modern Science (Cambridge: Harvard University Press,1989), pp. 12-13; Patricia H. Labalme, ed., Beyond their Sex: Learned Women of the European Past (New York: New York University Press, 1984).

${ }^{3}$ Offen, European Feminisms, 31-33; Schiebinger, The Mind Has No Sex, 15-16. 
sexes should be the same in nature, if not in degree, and that women, considered not only as moral, but rational creatures, ought to endeavor to acquire human virtues ... by the same means as men, instead of being educated like a fanciful kind of balf being-one of Rousseau's wild chimeras." Still others, including Voltaire, thought women should have opportunities to serve in government. ${ }^{4}$

These arguments reached American women in the late eighteenth century. Judith Sargent Murray took a position similar to Wollstonecraft's by linking the development of reason to access to education: "We can only reason from what we know, and if opportunity of acquiring knowledge hath been denied us, the inferiority of our sex cannot fairly be deduced from thence." The logical power of these arguments failed to sway America's early politicians to include women in formal politics, despite their many contributions to furthering the revolutionary cause, but did fuel an ongoing conversation about the development and purpose of formal education for women. This conversation was pursued against the historical background of formal education for men in colonial America. ${ }^{5}$

Men's colleges had been established throughout the colonial period in America, modeled in part on the all-male colleges of Britain and Scotland. No such institutions existed for women. Women who desired advanced education might seek instruction from an educated male relative or attend one of the academies or seminaries that offered more than a postprimary curriculum. These institutions provided secondary and possibly postsecondary study, but the classical curriculum, including Latin and Greek, offered at the men's colleges was not available to American women in formal settings throughout the seventeenth, eighteenth, and the first half of the nineteenth centuries. And when a few colleges began admitting women before the Civil War, female students were either relegated to a less rigorous, feminized curriculum or, in the case of Oberlin, asked to perform domestic chores for their male counterparts. This situation began to change after 1865. But the precedent had been established by then. American higher education had been framed entirely based on what knowledge was most important for educating male leaders and professionals, what kinds of institutions would best educate them, what methods were most appropriate given cultural expectations of masculinity, and who was most fitted to teach them. When women began to penetrate that realm, in coeducational institutions, women's colleges, and eventually research universities, debates

${ }^{4}$ Mary Wollstonecraft, $A$ Vindication of the Rights of Women, with Strictures on Political and Moral Subjects [1792] (New York: W. W. Norton \& Company, Inc., 1967) , 75; Offen, European Feminisms, 38-45.

5Judith Sargent Murray, "On the Equality of the Sexes," in Alice S. Rossi, ed., The Feminist Papers: From Adams to de Beauvoir (New York: Columbia University Press, 1973), 19. 
raged about how the feminine presence would affect their masculine character, their intellectual rigor, and their extracurricular life. ${ }^{6}$

The story of higher education in the United States is a story that cannot be understood without thorough attention to gender as the fundamental defining characteristic of American educational institutions, ideas, and practices. If the historiography of education has fallen short in the treatment of gender, it has been in the assumption that gender is merely an important concept primarily for understanding access. As Linda Eisenmann notes, although historians of education have spent the past two decades building a body of literature exploring women's access and experience, the work has not had the kind of influence on the intellectual and institutional history of higher education that it has on social history in general or increasingly on the history of secondary education in the United States. If women were not there, the reasoning seemed to be, gender need not be studied. Except in rare cases and newly emerging work of the last ten or so years, historians of higher education have treated women as the added factor, the "other," to be contained in a chapter or a few sentences when writing about male institutions, practices, and norms as the central story, while women are the side story at given periods of history. I argue that gender is the central story of the history of higher education. We simply cannot understand the most basic and normative concepts shaping the development of formal education without analyzing for gender. Further, as gender has been defined and characterized within particular groups, including ethnic minorities and social classes, analyses of gender remain critical to understanding the experiences of these groups in relation to majority norms, in the case of education, those arising from and reflecting values of the white middle class. ${ }^{7}$

\footnotetext{
${ }^{6}$ See, for example, Barbara Miller Solomon, In the Company of Educated Women: $A$ History of Women and Higher Education in America (New Haven: Yale University Press, 1985); Lori D. Ginzburg, "The 'Joint Education of the Sexes': Oberlin's Original Vision," in Carol Lasser, ed. Educating Men and Women Together: Coeducation in a Cbanging World (Urbana: University of Illinois Press, 1987), 67-80; Barbara Miller Solomon, "The Oberlin Model and Its Impact on Other Colleges," in ibid., 81-90.

'Linda Eisenmann, "Reconsidering a Classic: Assessing the History of Women's Higher Education a Dozen Years after Barbara Solomon," Harvard Educational Review 16 (Winter 1997): 689-717. See, for examples of lack of influence: Roger L. Geiger, To Advance Knowledge: The Growth of American Research Universities, 1900-1940 (New York: Oxford University Press, 1986) and idem., Research and Relevant Knowledge: American Research Universities since World War II (New York: Oxford University Press, 1993); David O. Levine, The American College and the Culture of Aspiration, 1915-1940 (Ithaca: Cornell University Press, 1986); Sheldon Rothblatt, The Modern University and Its Discontents: The Fate of Newman's Legacies in Britain and the United States (Cambridge: Cambridge University Press, 1997); Christopher J. Lucas, American Higher Education: A History (New York: St. Martin's Press, 1994). Examples of integration of gender in histories of secondary education: David Tyack and Elisabeth Hansot, Learning Together: A History of Coeducation in American Scbools (New Haven: Yale University Press, 1990); John Rury, Education and Women's Work: Female Schooling and the Division of Labor in America (Albany: State University of New York Press, 1991); William J. Reese, The Origins
} 
American intellectual and cultural historians, who have integrated gender in promising and theoretically rich ways into their studies, have not demonstrated much interest in close examination of higher education. One reads the literature exploring the history of feminism and finds allusions to the centrality of education in the development of feminist consciousness and, subsequently, to women's full economic and political participation; one also reads about the significance of gender constructions in understanding cultural and social change in United States history. However, rarely are the processes and institutions of education themselves explored in these accounts. Access to formal education and the opportunity to use it have been under analyzed in the literature of the history of feminism. ${ }^{8}$

\section{A Word on Theory}

Joan Scott's definition of gender is instructive for looking at the history of education: "a constitutive element of social relationships based on perceived differences between the sexes," as well as "a primary way of signifying relationships of power. ... Power is articulated," she suggests, through "culturally available symbols," often contradictory; "normative concepts," in religious, educational, legal, and scientific doctrines that interpret the meanings of those symbols; policies and practices of social institutions that construct, maintain, or challenge ideas and practices based in gender; and subjective identities-how individuals acted on and shaped gender identity in relation to gender constructions. Barbara Melosh notes that feminist historians have explored how "discourses of gender not only regulate the behavior of men and women," but also become "ways of ordering politics and of maintaining hierarchies." Further, historians have explored the gaps between discourse and experience to discern who was and was not influenced by these discourses and why. ${ }^{9}$

of American High School (New Haven: Yale University Press, 1995); Karen Graves, Girls' Scbooling during the Progressive Era: From Female Scholar to Domesticated Citizen (New York: Garland Publishers, 1998); and Kim Tolley, The Science Education of American Girls: A Historical Perspective New York: RoutledgeFalmer, 2003). Recent work that has integrated gender in studies of higher education: Solomon, In the Company, which focuses entirely on women's experience; Lynn D. Gordon, Gender and Higher Education in the Progressive Era (New Haven: Yale University Press, 1990); Patricia Ann Palmieri, In Adamless Eden: The Community of Women Faculty at Wellesley (New Haven: Yale University Press, 1995); Amy Thompson McCandless, The Past in the Present: Women's Higher Education in the Twentieth-Century American South (Tuscaloosa: University of Alabama Press, 1999).

${ }^{8}$ Exceptions include Gerda Lerner, The Creation of Feminist Consciousness: From the Middle Ages to Eighteen-Seventy (New York: Oxford University Press, 1993), ch. 9, and Linda Kerber, Toward an Intellectual History of Women: Essays (Chapel Hill: University of North Carolina Press, 1997), chs. 1 and 9.

'Joan Wallach Scott, "Gender: A Useful Category of Analysis," in Scott, ed., Feminism in History (Oxford: Oxford University Press, 1996), 167, 168; Barbara Melosh, "Introduction," in Melosh, ed., Gender and American History since 1890 (New York: Routledge, 1993). 
Gerda Lerner argues that historians' task is to examine how men and women have struggled over issues of power because in the realms of learning and politics the "ultimate consequence of men's power to define-the power to define what is a political issue and what is not-has had a profound effect on women's struggle for their own emancipation ... and has literally aborted and distorted the intellectual talents of women for thousands of years." As Geraldine Clifford and Ellen Lagemann suggest, we need to study how institutions resisted change to preserve gender distinctions and hierarchies and we need to study how women and men challenged those institutions to create more elastic and equal roles for men and women and less oppositional definitions for masculinity and femininity. ${ }^{10}$

\section{How Theories of Gender Reframe the History of Higher Education}

If, as Lerner claims, access to education was critical to the creation of feminist consciousness, which became a tool for challenging traditional gendered hierarchies, we must think of gender as a fundamental category that shaped hierarchy and power within and among educational institutions. Gendered assumptions organized their missons and practices. Gender was repeatedly invoked to justify relations of power within them, as well as the introduction of new institutional forms, the establishment of professions and the requirements of professional expertise, and the relationships among professions and educating institutions. Placing gender at the center of higher education history is not just a process of restoring who was left out of the historical narrative but rather reconceptualizing the history of higher education with a focus on gender "as a primary field within which or by means of which power has been articulated" in educational institutions. ${ }^{11}$

One way to think about this is to envision education as a field in which men have been repeatedly displaced by women, particularly as this displacement has occurred in areas of education that have declined in value, power, or status in relation to larger social changes. Another is to examine closely, as Nancy Beadie does, the relationship between institutions and the bodies founding them, including religious organizations and the state, to understand where and how they confirmed or contradicted larger state interests in legislating gender categories, roles, and relations. And a third way, as Kim Tolley has done with her study of secondary science education, is to

${ }^{10}$ Lerner, The Creation of Feminist Consciousness, 10; Ellen Condliffe Lagemann, "Looking at Gender: Women's History," in Historical Inquiry in Education, ed. John Hardin Best (Washington, D.C.: American Educational Research Association, 1983), 251-64; Geraldine Jonçich Clifford, "Shaking Dangerous Questions from the Crease: Gender and American Higher Education" Feminist Issues 3 (Fall 1983): 3-62.

"Scott, Feminism in History, 169. 
examine how the relative valuing of certain kinds of knowledge changed over time and worked with gendered assumptions of appropriate male and female activity (often based on beliefs about innate capacity) to influence who participated in what kinds of science education in which periods. ${ }^{12}$

Here, I explore the ways that gender and power functioned in shaping how women began to penetrate the male-dominated academic profession, particularly in the social sciences, an area in which women had some social authority as coreformers with men and reformers in their own right by the late nineteenth century. Women entered academe as professionals through the women's colleges that opened in the latter half of the nineteenth century. Unlike the colleges that served the male population, there was no continuous tradition of women's advanced formal education to guide their founders, early administrators, and faculty. Advanced education for noblewomen in Europe had almost entirely disappeared with the rise of medieval universities and the closing of convents during the Reformation. Men's colleges had been established throughout the colonial period in America. The earliest women's colleges in the United States followed the earliest men's college by more than two centuries. Most were located on rural campuses; others emerged in urban areas after intense lobbying and fund-raising by women and men attempting to expand the existing educational system and provide further study for the growing numbers of female high school graduates. Still others opened as public institutions to reach a broader pool of young women. A few, but not all, began with an explicit agenda to offer postsecondary education to young women, in some cases to help fill the teaching ranks of the expanding public education system, and in all cases to offer women educational opportunities on par with their brothers. ${ }^{13}$

During the 1880s and 1890s educators began making the argument that it was appropriate to extend women's teaching to the college level.

\footnotetext{
${ }^{12}$ Nancy Beadie, "Internal Improvement: The Structure and Culture of Academy Expansion in New York State in the Antebellum Era, 1820-1860," in Chartered Schools: Two Hundred Years of Independent Academies in the United States, 1727-1925, ed. Nancy Beadie and Kim Tolley (New York: RoutledgeFalmer, 2002), 89-115, and Beadie, "Emma Willard's Idea Put to the Test: The Consequences of State Support of Female Education in New York, 181967," History of Education Quarterly 33 (Winter 1993); Tolley, The Science Education of American Girls.

${ }^{13}$ On women's colleges and women faculty, see also Solomon, In the Company of Educated Women; Palmieri, In Adamless Eden; Helen Lefkowitz Horowitz, Alma Mater: Design and Experience in the Women's Colleges from Their Nineteenth-Century Beginnings to the 1930s (Boston: Beacon Press, 1984); Polly Welts Kaufman, ed., The Search for Equity: Women at Brown University, 1881-1991 (Hanover, N.H.: University Press of New England for Brown University, 1991). On women faculty in coeducational institutions, see Geraldine Jonçich Clifford, ed. Lone Voyagers: Academic Women in Coeducational Universities, 1870-1937 (New York: Feminist Press at the City University of New York, 1989). See also Thomas Woody, $A$ History of Women's Education in the United States (2 vols.; New York: The Science Press, 1929), on the development of schools, academies, seminaries, and colleges for women in the United States.
} 
Women, who had been teaching in primary schools since the early nineteenth century and in secondary schools and academies for women since the end of the eighteenth, were considered appropriate transmitters of knowledge, particularly when the students were young women. But women used their college positions to extend that role into the production of knowledge, the last bastion of male control of the politics of knowledge. Such a move began a long stop-and-go process of reshaping gendered power relations in academe. Women challenged existing beliefs about who could and should produce knowledge by demanding and gaining admission to graduate programs and by carrying their research agenda into what had been viewed as teaching-focused institutions. A number of factors shaped their access, their ability to participate, and their impact on these institutions.

Over the second half of the nineteenth century the authoritative foundations of patriarchal power eroded and secular governance increased. As the social and political power of the clergy declined, universities shifted their cultural and structural orientation to develop their capacity not just for the transmission of knowledge, but also its production. Scientific methods-empirical research, inductive reasoning, and the like-became prominent values shaping institutions, preparing academic professionals, and determining the kinds of knowledge considered valid, particularly in the sciences and social sciences. Because science was becoming the dominant mode of inquiry in universities, epistemological authority shifted, as Julie Reuben argues, from traditional sources to the empirical work of professional researchers. At the same time, the profession was male dominated, although a small number of women taught at women's colleges. ${ }^{14}$

Women students gained access to women's colleges and coeducational institutions in this period by using financial, social, and political pressure, exploiting whatever meager openings were initially offered, and developing meritocratic as well as specifically gendered arguments to justify their demands. At the same time, women enrolling in state universities and attempting admission to graduate programs encountered a larger cultural crisis in masculinity. Women's efforts to obtain suffrage and middleclass women's social reform activities threatened male power and control of politics and had a cumulative impact on concerns about maintaining clear distinctions between manliness and womanliness by the 1880 s and 1890 s. Universities provided an important site for the articulation and negotiation of this crisis. According to Gail Bederman, "middle-class men, uncomfortably confused about the nature and sources of male power, began to cast about for new ways to fortify their shaky constructions of manliness."

${ }^{14} \mathrm{Julie}$ Reuben, The Making of the Modern University: Intellectual Transformation and the Marginalization of Morality (Chicago: University of Chicago Press, 1996); Laurence R. Veysey, The Emergence of the AmericanUniversity (Chicago: University of Chicago Press, 1965). 
She claims that they focused on the discourse of civilization, using eugenics and nativist assumptions about the superiority of white males to distinguish themselves from women, Blacks, southern and eastern Europeans, and Indians. In this discourse, "extreme sexual difference was seen as a hallmark of civilization's advancement." It served manliness to characterize males as strong breadwinners, producers, and leaders, and females as fragile, dependent, and subservient reproducers. ${ }^{15}$

The construction of manliness that emerged at Harvard in the 1880s and $1890 \mathrm{~s}$ was reflected at other higher education institutions that saw as their central mission the education of men. To the Harvard faculty manhood rested on a certain kind of strong-mindedness and engagement in physical activity. A gentleman ought to select a profession, support a family, and distinguish himself by making a mark intellectually or professionally. He required a wife to help tame his erotic and violent emotions, to soothe his psychic traumas, and to serve his needs. Women, in this view, were morally elevated beings with the power to purify the domestic sphere and in limited ways other spaces, but were not autonomous individuals. Manliness depended on a man's ability to maintain dominance in his own household and particularly over his wife in ensuring that his needs were met. It demanded a strong will and disciplined habits, as well as a vigorous intellect. Most of all it required the ability to remain separate from women in certain aspects of life in order to maintain masculine strength and health. It is, then, no surprise that an institution like Harvard resisted coeducation for more than eighty years after founding the Annex that became Radcliffe College and refused to appoint women to the faculty. ${ }^{16}$

These concerns about masculinity held cultural currency at the same time that women were entering higher education institutions at unprecedented rates, numerically equaling men in some universities, and excelling in academic performance. Colleges and universities were the rubicon of male dominance in education. Protecting them from the incursions of women and African Americans was a matter of white masculine honor. One form of protection was to bar women's entry to undergraduate programs at male institutions, which is what the Ivy League institutions did. Another, illustrated by Lynn Gordon's study, was to marginalize women once on campus, as most coeducational institutions and graduate schools did. According to Christine Ogren, normal schools, where women participated with men in academic programs and in creating extracurricular activities, were an exception among coeducational institutions. However, these schools

\footnotetext{
${ }^{15}$ Gail Bederman, "Ida B. Wells's Anti-Lynching Campaign," in Melosh ed., Gender and American History since 1890, 211, 213.

${ }^{16} \mathrm{Kim}$ Townsend, Manbood at Harvard: William fames and Others (Cambridge: Harvard University Press, 1996), chapter 1 and pp. 200-55.
} 
were dismissed by the academic elite as being of lower status in comparison to colleges and universities. Unlike the women's colleges and normal schools, the coeducational universities and graduate programs treated the male student as the norm and the female student as "other." African-American students-male or female-who gained admission to all but historically black institutions were even further marginalized. ${ }^{17}$

Turned away from graduate study in the United States, some women enrolled in European universities in the 1880s and 1890s and were admitted, even though some of these institutions refused to train European women, because it was assumed the Americans would return to their home country rather than seek academic positions in Europe. In response to this competition from abroad, and to help staff the women's colleges, American universities began admitting women to master's and doctoral programs in the 1890 s. Such an alteration in policy put the shifting social and structural organization of universities in tension with cultural concerns about maintaining masculine power. If the institutions were to be governed by commitment to the empirical findings of science, the results of the work rather than the moral or cultural authority of the researcher, then the quality of the researcher's training as well as the knowledge produced should determine who gained access to the profession. When male faculty agreed to work with women graduate students, it was this kind of reasoning and commitment that shaped their willingness to do so. Yet, when women completed their advanced degrees, their male mentors rarely recommended them for positions in the kinds of institutions that had trained them. Instead they were encouraged to seek positions in the women's colleges. ${ }^{18}$

\section{Gender and the Women's Colleges}

The women's colleges opened their doors with the self-conscious understanding that they were reaching out to a constituency that was "different" from those at the majority of existing institutions. Although they each exhibited distinct contexts and goals, they all focused on succeeding in the education of women. This mission was reflected in building design, campus location, curricular decisions, and-the focus here-the appointment and treatment of faculty and administrators. They began with an explicit agenda to offer advanced education to young women, to help fill

\footnotetext{
${ }^{17}$ Gordon, Gender and Higher Education; Christine A. Ogren, "Where Coeds Were Coeducated: Normal Schools in Wisconsin, 1870-1920," History of Education Quarterly 35 (Spring 1995): 1-26; Linda M. Perkins, "The African-American Female Elite: The Early History of African American Women in the Seven Sister Colleges, 1880-1960," Harvard Educational Review 67 (Winter 1997): 689-717; McCandless, The Past in the Present.

${ }^{18}$ The earliest was the University of Zurich, followed by the University of Paris; Thomas Neville Bonner, To the Ends of the Eartb: Women's Search for Education in Medicine (Cambridge: Harvard University Press, 1992), 31-56.
} 
the teaching ranks of the expanding public education system, and to offer women educational opportunities on par with their brothers. ${ }^{19}$

Hiring women faculty enabled the women's colleges to distinguish themselves from other public and private collegiate-level institutions that began admitting women in the 1870s because they could attract the most highly educated women in the country. In addition, they offered women an opening into academe. By taking positions as faculty, women directly challenged the gendered assumptions that professional work and college teaching were and should continue to be male occupations. Judging by the swelling ranks of women faculty, they were anxious to make such a challenge. Women entered college-level teaching in increasing numbers after the Civil War, and by 1890 , comprised more than 13 percent of coeducational college faculties and 72 percent of women's college faculties. This was, of course, in the period before advanced degrees were expected for faculty; scholarship was just beginning to be an important activity of the professional academic. Although by 1900 more than twice as many women were enrolled in coeducational universities and colleges as in the women's colleges, the majority of women faculty were employed in single-sex institutions (and teachers colleges and normal schools in which the majority of students were women) and by the 1940s, represented 72 percent of the twenty-two largest women's college faculties. The women's colleges were for women critical entry points to academic life. ${ }^{20}$

${ }^{19}$ On women's colleges and women faculty, see also Solomon, In the Company of Educated Women; Palmieri, In Adamless Eden; Horowitz, Alma Mater; Kaufman, ed., The Search for Equity. On women faculty in coeducational institutions, see Clifford, ed. Lone Voyagers. See also Woody, A History of Women's Education in the United States, on the development of schools, academies, seminaries, and colleges for women in the United States.

${ }^{20}$ Lucille Addison Pollard, Women on College and University Faculties: $A$ Historical Survey and a Study of Their Present Academic Status (New York: Arno Press, 1977), 152-53, on the growth of nineteenth-century women faculty. Mabel Newcomer, A Century of Higher Education for Women (New York: Harper \& Brothers, 1959), 165, on the proportion of women on the twenty-two largest women's college faculties; and A. Caswell Ellis, et al., "Preliminary Report of Committee W on Status of Women in College and University Faculties," Bulletin of the American Association of University Professors 7 (October 1921): 21-32. Susan Boslego Carter, "Academic Women Revisited: An Empirical Study of Changing Patterns in Women's Employment as College and University Faculty, 1890-1963," Fournal of Social History 14 (Summer 1981): 680 , Table 2, presents slightly different percentages for those years. On women's colleges and women faculty, see Solomon, In the Company of Educated Women; Horowitz, Alma Mater, Kaufman, ed., The Search for Equity. On women faculty in coeducational institutions, see Clifford, ed. Lone Voyagers. On Wellesley, see also Palmieri, In Adamless Eden; Jean Glasscock, ed. Wellesley College, 1875-1975: A Century of Women (Wellesley, MA: Wellesley College, 1975); Florence Converse, Wellesley College: A Cbronicle of the Years, 1875-1938 (Wellesley, MA.: Hathaway House Bookshop, 1939). On Vassar, see also Elizabeth Hazleton Haight, The Life and Letters of James Monroe Taylor: The Biography of an Educator (New York: E. P. Dutton \& Company, 1919); James Monroe Taylor and Elizabeth Hazleton Haight, Vassar (New York: Oxford University Press, 1915); Constance Mayfield Rourke, ed., The Fiftieth Anniversary of the Opening of Vassar College, October 10 to 13, 1915: A Record (Poughkeepsie, NY: Vassar 
To understand how women scholars contributed to transforming the gendered culture of higher education, it is important to grasp how the institutions treated women as professional teachers and scholars. Conditions and expectations at the colleges varied, often by gender of faculty and administrators, and were shaped by the institutions' financial resources. At Wellesley and Mount Holyoke the president, all or most of the faculty, and some members of the board were female. While Wellesley's presidents did not push faculty to obtain the Ph.D., the mark of the male academic professional, Mount Holyoke's Emma Woolley did. Bryn Mawr's Dean and then President M. Carey Thomas hired more men initially than women and required doctorates because she believed that was the way to establish Bryn Mawr's credibility as a research institution as well as a college; it was the lack of access to training for the Ph.D. that moved Thomas to create this space in Bryn Mawr for women graduate students. Goucher opened under male leadership, but after women were appointed to the presidency and deanship, the proportion of women faculty increased; by 1938 women were in the majority of faculty and of faculty who had Ph.D.s. New Jersey College for Women (Douglass) opened in the 1910s with a majority male faculty, but most men and women had Ph.D.s and all were subordinate to the Rutgers faculty. ${ }^{21}$

Women seized the opportunity to contest the masculine hold on academic professional culture and they used the women's colleges to do it. But they continued to encounter gendered assumptions even as they made headway on the faculties. At many of the institutions women were paid less than men, although this discrimination diminished by the 1920s, except at Douglass. Similarly, until the 1920s and 1930s, men typically outranked women, particularly at institutions with a strong male presence on the faculty. At Smith in the early years, the male president and trustees had appointed some women as faculty to serve as proper feminine models for students and relied on male faculty at nearby Amherst to teach the majority of courses. But by 1915, the faculty was one-third male; slightly fewer than half of full professors, two-thirds of associate professors, more than two-thirds of assistant professors, and most instructors were women. ${ }^{22}$

Beginning in the 1880s at Vassar, women professors began redefining the professional identity of the faculty. Women had initially been appoint-

College, 1916); Dorothy A. Plum and George B. Dowell, comps., and Constance Dimock Ellis, ed., The Magnificent Enterprise: A Cbronicle of Vassar College (Poughkeepsie, NY: Vassar College, 1961).

${ }^{21}$ Horowitz, Alma Mater explores the Seven Sisters' founding and early missions. See also Anna Heubeck Knipp and Thaddeus P. Thomas, The History of Goucher College (Baltimore: Goucher College, 1939) and George P. Schmidt, Douglass College: A History (New Brunswick: Rutgers University Press, 1968).

${ }^{22}$ Myra M. Sampson, "Report on the Status of Women: Faculty of Smith College," 3; proportions compiled by President Burton, in same, 5, Myra M. Sampson Papers, Smith College Archives. 
ed as teachers whose primary obligation was to the preparatory department and men were hired as professors and heads of departments in the college proper. These women were required to live among students and supervise dormitory life, while men were encouraged to live in separate houses with their families, and, unlike women, were paid enough to afford such housing. Women and men were expected to focus on teaching, although the administration tolerated research as long as teaching remained the primary obligation of faculty. But more women who had pursued graduate study were appointed as professors in the 1880s and began to contest Vassar's differential treatment of women; Vassar's male presidents had to contend with an increasingly strong majority female faculty in the 1910s. By 1918, 100 percent of Vassar's faculty held the Ph.D., in comparison with 75 percent at Mount Holyoke, 67 percent at Harvard, 50 percent at Wellesley, and 43 percent at Barnard. ${ }^{23}$

Although Barbara Rossiter argues that women were unable to reform. academia's gender discrimination and reduce resulting limitations on women academics' professional advancement, she acknowledges that many colleges actually expanded their faculties, raised salaries, and increased classroom and laboratory space from the 1910s through the 1930s. But she does not explore the multiple ways that women faculty themselves shaped collegiate institutions to enhance women's professional development and accommodate them as producers as well as transmitters of knowledge. Colleges had different ways of responding to their demands and supporting women as professional scholars: allowing them to teach courses in their research areas, offering regular sabbaticals, expanding library collections in response to research needs, providing teaching and research assistance by graduate and undergraduate students, expanding departments, encouraging travel to conferences and professional meetings, hiring a critical mass of women to serve as mentors, recognizing women faculty as professional colleagues of, rather than subordinates to, male faculty, offering incentives through promotion and salary raises, and providing faculty and graduates with research fellowships. In short, because women faculty and administrators pressured the women's colleges to recognize their needs as scholars, assistance that had become increasingly available to male faculty at research universities and male colleges from the 1890s became available to women at the women's colleges in the first third of the twentieth century. ${ }^{24}$

${ }^{23}$ Mabel Louise Robinson, The Curriculum of the Woman's College (Washington, D.C.: Department of the Interior, Bureau of Education Bulletin No. 6, 1918), 100, on the percentages of Ph.D.s; she gives Harvard's percentage as Radcliffe's, but Radcliffe had no faculty apart from Harvard's. Exceptions to the faculty norm in Vassar's early years were astronomer Maria Mitchell and physician Alida Avery, who were appointed as professors.

${ }^{24}$ Barbara Rossiter, Women Scientists, ch. 7. See the following on these different kinds of supports: Hutchinson, Women and the Ph.D.; Hawthorne, "Women as College Teachers"; Helen Sard Hughes, "The Academic Chance," Fournal of the Association of Collegiate Alumnae 


\section{Gender, the Women's Colleges, and Social Science Scholarsbip}

For social science scholars, a critical issue was the extent to which the colleges committed to providing social science study in the curriculum. The most fully articulated programs by the 1920 s were at the northeastern colleges and Goucher, where the numbers of women faculty were highest in economics, history, sociology, and political science. Developments in collegiate programs took decades to unfold. The demand for social science research to address social and economic problems, students' desire to study social sciences, and faculty pressure to expand social science course offerings led the colleges to recognize the rising importance of the social sciences as disciplines.

Vassar offers an example of how women faculty successfully pressed the college to recognize them as scholars and acknowledge the value of their scholarship. Lucy Salmon initiated regular teaching in history, introducing five courses in her first year on the faculty (1887-88), which early established history as an important department in the college. She rejected the college's gender-based requirement that female faculty live with students, while male faculty were exempted, as well as the underlying assumption that academic professionalism could make different demands on men and women. She described this expectation for women as "the clink of chains and the key turned in the door," where one had to "get up by a bell [and] eat by a bell." Economist Herbert Mills was appointed to the history faculty in 1890. Because President Taylor had promised him a chairmanship, and Mills was not happy working "under" Salmon, Taylor made Mills chair of the newly separate economics department three years later. Where by 1910 Salmon persuaded Taylor to provide clerical support, expand library resources, and add nine history faculty with doctorates, Mills added only one economist, a Vassar B.A., as an assistant in economics. This suggests the kind of impact a determined scholar pressing for support had on an institution, even one perennially stretched for funds and somewhat resistant to women's full professional equality. ${ }^{25}$

Barnard College initially relied on the all-male Columbia faculty to offer courses to its students. When Dean Emily James Putnam and President Seth Low proposed adding two professorships to Columbia's School of Political Science in exchange for "a corresponding amount ... of separate instruction to Barnard seniors and graduates," the school's Dean, John

12 (January 1919): 79-82. On salaries, see Stricker, "American Professors in the Progressive Era: Incomes, Aspirations, and Professionalism," Fournal of Interdisciplinary History 19 (Autumn 1988): 231-57.

${ }^{25}$ Lucy Salmon to Adelaide Underhill, 5 August 1900 and 23 August 1900, quoted in Louise Fargo Brown, Apostle of Democracy: The Life of Lucy Maynard Salmon (New York: Harper \& Brothers, 1943), 180, 176. Robinson, The Curriculum of the Woman's College. On Vassar's departments, see History and Economics "Reports," Archive Files, Vassar College Archives. 
W. Burgess, lowered his long-standing resistance to educating women and sharing faculty. By 1900, Barnard organized its own faculty and began appointing women as assistants who then rose in the ranks. Where Vassar had male presidents, but a majority of women faculty in social sciences after 1900, Barnard had female deans whose authority was limited by the president of Columbia University and department chairs who typically were male. But those deans' efforts were crucial in reshaping gendered power at Barnard. The faculty, many of whom had completed the doctorate at Columbia, shifted from 21 percent female in 1900 to 61 percent female by 1940. In social sciences, the numbers of women increased slowly from one in 1900 to approximately 12 in 1940, but most were in short-term appointments at low ranks. Women seeking advancement relied on male colleagues' assessments of their scholarship and teaching, often remaining at the instructor level for as long as eight to ten years after completing the doctorate. Their male counterparts rose quickly through the ranks or, having greater options available, moved elsewhere. Male faculty were expected to produce research and advance academically, while female faculty were expected to teach and, if they did research, eventually receive promotion. But the fact that the numbers and proportions of women grew by 1940 suggests that those at Barnard had succeeded in chipping away at these assumptions. ${ }^{26}$

A contrast can be found in Mount Holyoke's social science departments. President Woolley was committed to creating an institutional culture in which women exercised considerable power in shaping the social science programs and the professional criteria for advancement. She sought women with demonstrated interest in research and appointed strong women to the history department, from which economics, sociology, and political science developed. Woolley collaborated with faculty department chairs in growing these departments. Unlike Salmon's continuing struggle for expansion of the work in history, and the Barnard women faculty's for recogni-

${ }^{26}$ R. Gordon Hoxie, et al., $A$ History of the Faculty of Political Science, Columbia University (New York: Columbia University Press, 1955), 66-67. See also Robert A. McCaughey, "A Statistical Profile of the Barnard College Faculty, 1900-1974," (typescript, Department of History, Barnard College, 1975), Barnard College Archives. I extrapolated the number from his figures in tables I.4, II.1, and II.5, based on a decadenal analysis, which includes part-time appointments. My own count reveals only 6 in 1940, all full-time and most with voting privileges on the faculty. My search was less exhaustive because I was interested in women who remained long enough to have some impact on the institutional culture at Barnard; see Mary Churchill White, A History of Barnard College, ed. Eleanor S. Minitz (New York: Columbia University Press, 1964), 117-126, and Dean's Office and Departmental Papers, Barnard College Archives (DODP, BCA). The practice of delaying election to the faculty existed at Columbia for junior faculty: Hoxie, et al., $A$ History of the Faculty of Political Science, Appendix C. On deans, see Andrea Walton, "Achieving a Voice and Institutionalizing a Vision for Women: The Barnard Deanship at Columbia University, 1889-1947," Historical Studies in Education 13:2 (Fall 2001): 113-46; Jana Nidiffer, Pioneering Deans of Women: More than Wise and Pious Matrons (New York: Teachers College Press, 2000). 
tion of their roles in social science development, Mount Holyoke's social science faculty led the way in shaping the departments' teaching and research agendas. They created a professional sphere for women in which seniority and duration on the faculty had more impact than gender on power relations among the faculty.

These examples illustrate the colleges' different levels of commitment to the social sciences and to women as professional social scientists. Such commitment depended on the extent to which the president was able to enlarge the faculty, to recognize the faculty role in developing academic programs, and to grasp the growing importance of the social sciences in the early twentieth century. As the colleges began hiring faculty with a commitment to such research and to furthering women's involvement in social science study and scholarship, women faculty increasingly devoted their efforts to shaping the institutions' cultures to accommodate scholarship and teaching. While this effort was somewhat constrained at an institution like Barnard, with its close affiliation with Columbia, where male chairs and colleagues controlled advancement and promotion, and Mount Holyoke, with its limited finances but more accommodating policies, it was less so at a place like Bryn Mawr. At Bryn Mawr Thomas succeeded in appointing male faculty who helped to establish the departments of economics and history but also routinely hired women. She was able to expand social sciences in 1915, using a bequest to create the Graduate Department of Social Economy and Social Research, which granted both masters and doctoral degrees and assumed responsibility for instruction in statistics, as well as for training social workers. ${ }^{27}$

Goucher, like Mount Holyoke and Vassar, developed its social science program out of the history department and appointed faculty with doctorates. From the 1890s that department was populated with more women than men. Economics did not really gain separate status and faculty until the 1920s, and then had four women and one man, while sociology developed in the later 1910s, and held only one faculty member in the 1920s. And political science emerged in 1920, staffed by two men and one woman into the 1930s, a response to the Nineteenth Amendment granting women the suffrage. These kinds of developments suggest a growing commitment to social science throughout the period mitigated by the normal budgetary constraints and other long-standing priorities at Goucher, particularly in the sciences and humanities, which tended to be more fully staffed. Because women stayed, they had a long-term impact on the academic culture, which enabled them to provide a research ethos for students and junior faculty that demonstrated the viability of women as

${ }^{27}$ Mary Ann Dzuback, "Women and Social Research at Bryn Mawr College, 19151940," History of Education Quarterly 33:4 (Winter 1993): 579-608. 
producers of knowledge. In a city whose knowledge production was dominated by The Johns Hopkins University with its predominantly male faculty, Goucher women challenged the assumption that research was a male domain..$^{28}$

Smith differed from the other nonaffiliated women's colleges in its early commitment to both social sciences and appointing male faculty to develop social science programs. The Department of History and Political Economy attracted promising young men by the 1890 s, admitting one woman to their circle in the early 1900 s, but by the 1920 s, Smith had nearly as many long-term women faculty as men. The women received encouragement and respect from such equitably minded colleagues as Merle Curti, who joined the faculty in 1925. Economics and sociology grew in a similar way and women were in the majority of both by the 1940s. What this pattern suggests is that, although men created and developed social science programs at Smith and used the college to launch their own scholarly careers, as women with doctorates were added and slowly promoted, they gained increasing power in shaping those programs in the 1920s and 1930s, and, like Goucher, illustrating for their students and junior colleagues an alternative vision of knowledge production. ${ }^{29}$

As Barbara Rossiter suggests, from the 1910s through the 1930s, except at the low points of the depression, all the women's colleges benefited from the expansion of higher education in the United States and added significantly to their faculties. This was particularly true for struggling institutions gaining accreditation after the turn of the century, including Sweet Briar, Hollins, Douglass, and Connecticut Colleges. These institutions typically maintained combined social science departments into the 1920s. The one or two faculty hired in a department had to do double or triple duty to expand the social sciences. Administrative and trustee attitudes about social science programs changed typically after a scholar was appointed dean or president and in a position of power to make arguments about deployment of resources. By the 1930s, students' interest in social science courses, and the social problems made evident by the depression, provided further ratio-

${ }^{28} \mathrm{Knipp}$ and Thomas, The History of Goucher College, 569-82, lists all faculty to 1938 . Both Bryn Mawr and Goucher had faculty in education as well. This was quite common at all the women's colleges, as most college graduates who worked went into teaching at least until they married, and often continued after marriage. Many women who eventually obtained Ph.D.s, hoping for academic employment, taught before entering graduate school and, when the academic job market constricted, returned to high school teaching after finishing advanced degrees.

${ }^{29}$ See Mary Breese Fuller, "Development of History and Government in Smith College, 1875-1920," Smith College Studies in History 5 (April 1920): 139-173; Charles H. Page, Fifty Years in the Sociological Enterprise: A Lucky fourney (Amherst: University of Massachusetts Press, 1982), ch. 4; Faculty Files, Smith College Archives (FF, SCA). On college curricula, see Robinson, "Curriculum of the Woman's College," for Vassar, Wellesley, Barnard, Radcliffe, and Mount Holyoke. 
nales and pressure for shifting resources to social sciences. At all of these colleges, men were only slightly more advantaged than women because of the limited resources. Women were able to create a place in which a few women scholars could uphold the professional research model of modern scholarship. And it is clear that in the larger context of male-controlled academic scholarship, women at the smaller colleges struggled most among women scholars to continue working as professional scholars. ${ }^{30}$

At Sweet Briar College, President Emily McVea pushed for the development of social science courses and opportunities for social and community service. Her successor, Meta Glass, appointed eighteen faculty during her twenty-year tenure-four of whom were scholars in the social sciences. She recruited Helen Dutton as dean to foster faculty research and enable students to develop research projects. Social science departments at Hollins, a former seminary, were initially staffed by Hollin's graduates with B.A.s. Most of the faculty to the 1920s taught history. Gladys Palmer's appointment to the new economics and sociology department in the middle 1920s was the first sign that Hollins was willing and able to expand its social sciences program; the department held no more than two faculty throughout the 1930s. History also remained small but began hiring women with Ph.D.s in the middle 1930s under President Bessie Carter Randolph (Ph.D. Radcliffe 1926), who reorganized the faculty in 1933, creating a Division of Social Sciences, and strongly encouraged faculty scholarship. In both of these cases, female administrative leadership and the commitment of faculty to scholarship transformed these institutions to allow a research culture to develop and advance possibilities for women researchers. ${ }^{31}$

At historically black women's colleges in the South, social science study, women faculty with higher degrees, and research were delayed for another two decades by the exclusion of black women from doctoral programs, financial constraints on black women pursuing any higher education, and the limited finances of the institutions themselves. Very few developed doctoral programs until the middle of the twentieth century. For that reason, they are not part of this study. But the growing scholarship in this area suggests that black women faculty in these years provided critical

${ }^{30}$ Rossiter, Women Scientists, 168-69.

${ }^{31}$ On Sweet Briar, see Martha Lou Lemmon Stohlman, The Story of Sweet Briar College (Sweet Briar, VA: Alumnae Association of Sweet Briar College, 1956), 236-46; on Hollins: Dorothy Scovil Vickery, Hollins College, 1842-1942: An Historical Sketch, Being an Account of the Principal Developments in the One-Hundred-Year History of Hollins College (Hollins College, VA: Hollins College, 1942, and Frances J. Niederer, Hollins College: An Illustrated History [1973] (Charlottesville: University Press of Virginia, 1985); "Department of Sociology and Economics at Hollins," Hollins Alumnae Quarterly (July 1930): 12. I am especially grateful to Beth Harris of the Hollins College Archives for her help locating archival materials and for compiling a list of social sciences faculty for me. 
mentoring to their students, who often were the first generation in their families to obtain a college education. ${ }^{32}$

Douglass College operated under different constraints. The university restricted its appointments of full-time faculty until the late 1920s. Dean Mabel Douglass ran the college as a kind of fief, basing appointments on both personality and scholarship, developing no formal criteria for promotion, and offering no tenure, which limited the faculty's ability to develop professional standards in line with the larger world of academia. She responded to pressure from New Jersey women's groups by appointing a number of women to the history and political science departments by the late 1920s. Sociology and economics on the other hand held far fewer faculty and no women before 1930. The first women full professors were not appointed until 1927, and those were mostly in humanities departments. Not until the 1930s did Douglass begin to address salary imbalances across gender. When Dean Margaret Corwin took office in 1934, she worked closely with department chairs to develop criteria for promotion and tenure and to expand curricular programs. Like Barnard, Douglass relied on strong deans to make its case to the university but unlike Barnard, depended on the New Jersey legislature and Rutgers for all of its financial support, which significantly slowed the development of social sciences for faculty and students. Connecticut College and Hunter experienced similar late and slow development for similar reasons, with one or two faculty in each social science department and few women with doctorates until the 1930s. ${ }^{33}$

At these smaller institutions faculty faced difficult challenges in their efforts to maintain professional standing as scholars. At Hollins, even with

\footnotetext{
${ }^{32}$ Some black women, for example Sadie Tanner Mossell, who attained the Ph.D. at the University of Pennsylvania in economics in 1921 and then a law degree, entered into law practice or fields other than academia. By the 1940s, when Merze Tate earned a Ph.D. in international relations from Radcliffe, academic positions were slowly beginning to open; Tate taught at Howard for thirty-five years. See V.P. Franklin, "Sadie Tanner Mossell Alexander," in Black Women in America: An Historical Encyclopedia (hereinafter BWA), Vol. I, ed. Darlene Clark Hine, Elsa Barkley Brown, and Rosalyn Terborg-Penn (Bloomington: Indiana University Press, 1993), 17-19, and Rosalyn Terborg-Penn, "Merze Tate," in $B W A$, Vol II, 11415. On the colleges and student struggles, see McCandless, The Past in the Present, ch. 4; Jeanne L. Noble, The Negro Woman's College Education (New York: Garland Publishing, Inc., 1987 [1956]), 24; Ina Alexander Bolton, "The Problems of Negro College Women" (Ph.D. diss., University of Southern California, 1949). Black parents wanted their daughters to be able to compete for the limited professional positions open to their educated daughters in the South; character was a critical qualification, particularly for black women; see Stephanie J. Shaw, What a Woman Ought to Be and to Do: Black Professional Women Workers during the fim Crow Era (Chicago: University of Chicago Press, 1996), ch. 5. Special thanks to Faustine JonesWilson for pushing me to explore this further in my draft of the book manuscript.

${ }^{33}$ George P. Schmidt, Douglass College: $A$ History (New Brunswick: Rutgers University Press, 1968). On Connecticut College, see Gertrude Noyes, $A$ History of Connecticut College (New London: Connecticut College, 1982) and Oakes Ames, Connecticut College: Contributing to a Changing Society (New York: The Newcomen Society of the United States, 1986); Grunfeld, "Purpose and Ambiguity," on Hunter; and Noyes, A History of Connecticut College.
} 
Randolph's support for faculty scholarship, teaching demands fell heavily on the few faculty in each department. If they wanted to teach in their areas of scholarship and at the same time develop the department's program, as those with doctorates increasingly did in the 1920s and 1930s, they found themselves in a double-bind: increasing course offerings placed significantly more demands on them. Or if one arrived at Hollins with a masters degree and some work toward the Ph.D., it was all the more difficult to finish the final degree while also carrying the teaching load and participating in local and state public service activities. A similar tension could be discerned at all the colleges, but those with fewer women scholars in the disciplines faced greater institutional and practical constraints. In developing as scholars and making arguments for supporting scholarship at their institutions, women encountered patterns of gender discrimination in salary, promotion, and community expectations that were easier to maintain when departments were controlled by male faculty or by administrators not committed to academic women's professional advancement in the social sciences. The clerical controls of an earlier period had been replaced by secular controls that were less restrictive but still gender-based.

The extent to which social science programs reflected faculty interest in research became an important factor in institutional support for scholars. At Vassar, Mount Holyoke, Goucher, and Smith a critical mass of scholars helped to foster the ethos of research for undergraduates, which in turn enhanced opportunities for faculty to engage students in the kinds of problems that interested them. The fact that Mount Holyoke and Smith continued to grant masters degrees helped them maintain contact with graduate students. Bryn Mawr's doctoral program supported faculty work with students whose primary reason for matriculating was to complete a major research project in their disciplinary area. This connection with other scholars and with graduate students enabled women to recreate on a much smaller scale the kind of working environment male scholars encountered in the research universities.

Public service played a key role for women faculty in furthering their scholarly programs. It was expected, particularly of faculty in the social sciences. Belle Boone Beard at Sweet Briar and Amy Hewes at Mount Holyoke served on state and federal boards addressing such issues as welfare, minimum wage laws, and conditions of women's work. Such service typically raised the scholar's research profile, increased her opportunities, and enhanced her institution's reputation. Both male and female faculty engaged in public service, but women faculty used these opportunities to extend their research and include their female students in the research enterprise. Without such involvement, women students were unlikely to have experienced first-hand research and its application to public service. Women faculty would have had little opportunity to work in this kind of capacity with stu- 
dents. In contrast, the combination of research and public service was routine for male social science faculty at the research universities. ${ }^{34}$

In 1931 the Social Science Research Council held a conference on social science research in the colleges. The report of this conference provides a means of assessing women scholars' impact on support for faculty research at twelve single-sex and coeducational colleges. The conference explored such issues as faculty salary scales, program funds in college budgets, research funds, and conditions affecting research, including teaching demands, sabbatical leaves, and library facilities. The support colleges provided varied significantly, despite the claim by representatives that "an overwhelming majority of the social science faculty" were "carrying on research." Comparatively speaking, the "superior salary scale of the men's colleges," the different levels of research funding, and the variation in use of sabbatical leaves appeared to be the factors most influencing institutional accommodation for research. But for all, "the relatively small number of instructors," size of the communities, and high expectations for honors work put heavy time demands on all faculty. The commitment to using sabbatical leaves for research appeared to be greatest at Bryn Mawr, Mount Holyoke, Smith, Vassar, and Haverford, somewhat less at Swarthmore and Wesleyan, and least at Amherst, Oberlin, Wellesley, and Williams. Moreover, most of these institutions provided no regular funds for faculty research. The women's colleges had special funds-typically alumnae donations-to help with research and publication. But as the report noted, "since [Council] grants are given only to those who have proved that they can do good research, and since research-workers in colleges are discouraged from undertaking large and expensive projects because of limited funds, investigators on the college level operate under unusual disabilities," even though "one out of every two applicants from smaller universities and colleges had received ... [Council] grants, while one of every three from the larger universities had received them." ${ }^{35}$

Clearly, by 1931, conditions were such that those colleges in which women faculty had developed a research culture had overcome sizable obstacles to support social science scholarship. At Vassar, women faculty pushed a professionalizing agenda, while their male colleagues, the board, and the administration were slow to respond. The situation changed gradually as more women faculty were appointed and then was fully transformed after 1915 when a new president took office. At Mount Holyoke, the president

${ }^{34}$ Belle Boone Beard Papers, Lynchburg College Archives; Belle Boone Beard Faculty File, Sweet Briar College Archives; Amy Hewes Faculty File, Mount Holyoke College Archives and Special Collections [hereafter MHCA].

3s"Summary of the Conference on Research in the Social Sciences in Colleges," 12 and 13 December 1931, file 1, Ethel B. Dietrich Papers, FF, MHCA, 14, 8, 10. Dartmouth was the twelfth institution, but no data from Dartmouth were included in the report. 
encouraged scholarly professionalism and hired and promoted faculty who furthered it; trustees came to agree with these goals over time, and alumnae offered strong support for developing the faculty's research capacity. Goucher had a commitment to scholarship from the beginning because of its association with Johns Hopkins, but the president was slow to share power and resources until a key dean stepped in to foster faculty research. A similar situation existed at Barnard, although Barnard's deans were often constrained by the administration and faculty of Columbia. But administrative and alumnae support were not enough. How the faculty resisted administrative and trustee efforts to curb their autonomy and limit their scholarship was key to transforming the culture of these institutions.

These efforts at transformation were shaped in part by the conditions in which women academic professionals lived and worked. In contrast to their male counterparts, women in the first generation of professional academic scholars, those obtaining positions in the twenty-five years between 1890 and 1915 , generally did not marry. They felt they had to choose between marriage and family and a professional career. The demands of domesticity and strong social pressures on middle-class women to devote full attention to their families precluded pursuing both. This was not the case for male faculty. Although women continued to respond to "the family claim," they did so as single women taking care of siblings, parents, and other family members, rather than spouses and children of their own. Many of these women lived on campus in student or faculty housing, but they also had some responsibility for financial and emotional support of their families of origin. Northern colleges shifted from expecting women faculty to live with and supervise students to recognizing that women faculty had social and professional obligations similar to their male counterparts. This was not the case in the South. Ensuring "ladylike" behavior and southern women students' virtue were part and parcel of the unmarried woman faculty member's responsibility well into the 1940s. When northern women faculty began moving off campus or into faculty housing in the early 1900s, they created family arrangements through homosocial domestic commitments in which two women lived and cared for their household together. ${ }^{36}$

The second generation, entering academia from the middle 1910s through the 1930s, tended to marry or live alone, although some preferred

${ }^{36} \mathrm{Jane}$ Addams quoted in Solomon, In the Company of Educated Women, 116; on this tension women experienced between family and work demands, see same, 130-140; Alison McKinnon, Love and Freedom: Professional Women and the Reshaping of Personal Life (Cambridge: Cambridge University Press, 1997); Nancy Cott, The Grounding of Modern Feminism (New Haven: Yale University Press, 1987), 221-222. For a specific example of how these living arrangements worked in one institution, see Palmieri, In Adamless Eden, ch. 8. On southern colleges, see McCandless, The Past in the Present, ch. 4; Shaw, Wbat a Woman Ought to Be and to Do, ch. 5; Noble, The Negro Woman's College Education, 24. 
the homosocial arrangements of their mentors. They optimistically believed that it was becoming more socially acceptable and pragmatically possible to have both a family and a career. However, in a number of such cases, women were denied positions in the institutions employing their spouses (nepotism rules), which made finding work difficult, or had great difficulty balancing the two demands. Among those who remained in academia and married, some lived apart from their spouses to pursue their work, others found positions in the few institutions that believed marriage and career were compatible, and still others moved between academia and public and private research agencies, or among institutions to remain with their spouses.

\section{Conclusion}

Women faculty used their positions in the colleges to shape collegiate culture to support them as scholars as well as teachers and to enable them to introduce their students to scholarly work. This commitment facilitated women's continuing challenge to penetrate the male world of academic research. Their goals included influencing these institutions to respond to them as autonomous professionals and to provide more financial and programmatic support for the social sciences-in short, to make good on the promises of meritocracy inherent in modern, scientific, research-based higher education. Their strategies ranged from the general to the specific. First, they pushed the colleges to emulate the university research culture, without sacrificing the primary mission of providing advanced education for young women. But because these were not research universities and lacked their basic assumptions and resources shaping faculty and student work, women scholars and supportive administrators focused on one or more characteristic of these institutions: pushing to increase the proportion of the faculty with the Ph.D.; offering graduate programs, usually at the masters level; rejecting top-down paternalistic leadership and demanding greater faculty autonomy and control of curriculum, recruiting, appointments, and use of time; ensuring the continuation and expansion of the institution's commitment to women faculty; and drawing students into the research enterprise in regular classes, honors programs, public service, and other activities.

Second, they offered mentoring into the academic profession to junior faculty and to students. This mentoring went beyond the more typical efforts to engage students in subject matter, missionary work, or voluntary social reform that had been part of college teaching for a good part of the nineteenth century. It was explicit and persistent in contrast with the passive examples of those women who simply served as role models by virtue of their presence and success as scholars. Mentoring focused explicitly on guidance into a world largely dominated and controlled by male 
professionals. Not unlike the mentoring their male colleagues provided at the men's colleges and universities, it nevertheless demanded specific and different kinds of tactics to enable women to develop the confidence and commitment to penetrate and persist in the male world of academic scholarship. This is not to suggest that women absolutely required such mentoring-many who entered the field only had successful male scholars as models - but the kind of guidance women scholars offered women was critical for helping them make contacts, negotiate institutional and professional association politics, deal with gender discrimination, and attract recognition for their scholarship. ${ }^{37}$

Third, women faculty brought funds into their institutions or demanded institutional funds, in some cases acquired through bequests, specifically for research, including library resources, sabbaticals, fellowships for graduates, and travel to professional meetings. They used a variety of tactics, often drawing on networks of alumnae, local women of wealth, and donors interested in fostering social research to inform policymaking. Some managed to obtain philanthropic foundation grants or fellowships when they became available in the 1920s and 1930s. Others parlayed sabbaticals into social service to gather data for their research, involve students in projects, and contribute their findings to public discussions of policy. In fact, these efforts-from implanting a research culture in the colleges, to mentoring colleagues and students, to raising funds-were enhanced by the public service women faculty performed, much like their male colleagues in social science, in contributing to local, state, and national public policymaking and implementation. Their work in the colleges enabled women to become professional scholars in academic social science. Because of the kinds of constraints they faced and the institutional cultures in which they worked, though, we cannot assume that they simply embraced the male model of scholarship. Instead, they shaped their work to fit their lives and their institutional and social commitments. ${ }^{38}$

For women academics attempting to redefine who could be considered a legitimate producer of knowledge, who could participate in the research enterprise of the modern, meritocratic university, and who could contribute to policy formation through research, the women's colleges were critical entry points in women scholars' challenge to gendered assumptions about the politics of knowledge. The women's colleges offered them oppor-

\footnotetext{
${ }^{37}$ I develop this further in a paper entitled "Passing the Torch: Academic Women and Professional Power," initially presented at the History of Education Society annual meeting in 2000 , and currently in revision for publication.

${ }^{38}$ I develop this further in a paper entitled "Creative Financing in Social Science: Women Scholars and Early Research," initially presented at the Social Science History Association annual meeting in 1999, and revised as a chapter in a forthcoming volume on the history of women and philanthropy.
} 
tunities that they otherwise would not have had. Their struggles exposed the failure of modern research universities to live up to their meritocratic assumptions and claims regarding the production of knowledge. Their successes had a slow, incremental influence on reshaping academic professional life over the course of the twentieth century in the United States. 